\title{
Characterization of Lipases from a Vegetable Oil Contaminated Soil Fungal Isolates
}

\author{
Moses Bali Emmanuel ${ }^{1, *}$, Liman Mubarak Labaran², Egwim Chidi Evans ${ }^{3}$, Abdulkadir Abubaka ${ }^{3}$, \\ Alex Victoria Ali ${ }^{1}$, Manya Zabe ${ }^{1}$ \\ ${ }^{1}$ Department of General Studies, School of Agricultural Technology, Nuhu Bamalli Polytechnic, Nigeria \\ ${ }^{2}$ Department of Science Laboratory Technology, School of Applied Sciences, Nuhu Bamalli Polytechnic, Nigeria \\ ${ }^{3}$ Department of Biochemistry, School of Life Sciences, Federal University of Technology, Nigeria
}

Received June 14, 2020; Revised August 1, 2020; Accepted August 25, 2020

\section{Cite This Paper in the following Citation Styles}

(a): [1] Moses Bali Emmanuel, Liman Mubarak Labaran, Egwim Chidi Evans, Abdulkadir Abubaka, Alex Victoria Ali, Manya Zabe, "Characterization of Lipases from a Vegetable Oil Contaminated Soil Fungal Isolates," Universal Journal of Microbiology Research, Vol. 8, No. 2, pp. 19 - 27, 2020. DOI: 10.13189/ujmr.2020.080202.

(b): Moses Bali Emmanuel, Liman Mubarak Labaran, Egwim Chidi Evans, Abdulkadir Abubaka, Alex Victoria Ali, Manya Zabe (2020). Characterization of Lipases from a Vegetable Oil Contaminated Soil Fungal Isolates. Universal Journal of Microbiology Research, 8(2), 19 - 27. DOI: 10.13189/ujmr.2020.080202.

Copyright $@ 2020$ by authors, all rights reserved. Authors agree that this article remains permanently open access under the terms of the Creative Commons Attribution License 4.0 International License

\begin{abstract}
Lipases are enzymes that hydrolyse lipids to produce free fatty acids and glycerol. Fungi were cultured on sabouraud dextrose agar (SDA) plates and identified using microscopic techniques. Screening for lipase producers was carried out on SDA media supplemented with $3 \%$ olive oil at ambient temperature. M. pusillus, $M$. canis, A. fumigatus, Yeast and T. mentagrophytes were found to produce lipases in different amounts with Yeast and $M$. canis being the highest producers, they were further characterised for this reason. Lipase production was carried out using submerged fermentation. Both Yeast and $M$. canis produced lipases maximally at $72 \mathrm{~h}$. Optimum $\mathrm{pH}$ and temperature of activity for the lipases from Yeast were determined to be 5 and $35{ }^{\circ} \mathrm{C}$ respectively whereas, those from $M$. canis were 6 and $40^{\circ} \mathrm{C}$ correspondingly. Yeast and $M$. canis lipases had preference for olive oil than vegetable and palm oils and both enzymes were activated by $\mathrm{K}^{+}$, $\mathrm{Mg}^{2+}$ and $\mathrm{Ca}^{2+}$ and inhibited by $\mathrm{Fe}^{3+}, \mathrm{Hg}^{2+}$ and $\mathrm{Co}^{2+}$. The lipase enzyme from Yeast had $\mathrm{V}_{\max }$ of $0.0006 \mathrm{U} / \mathrm{mL} / \mathrm{Sec}$, $\mathrm{K}_{\mathrm{m}}$ of $0.4242 \mathrm{mM}$ and $\mathrm{K}_{\text {cat }}$ of $0.0004 \mathrm{~S}^{-1}$ while that from $M$. canis had corresponding $\mathrm{V}_{\mathrm{max}}, \mathrm{K}_{\mathrm{m}}$ and $\mathrm{K}_{\text {cat }}$ of 0.0001 $\mathrm{U} / \mathrm{mL} / \mathrm{Sec}, 3.2287 \mathrm{mM}$ and $0.0001 \mathrm{~s}^{-1}$.
\end{abstract}

Keywords Fungal Isolates, Yeast, Microsporum canis, Lipases, Characterization

\section{Introduction}

Lipases (E.C. 3.1.1.3) are biological catalysts that break down fats and oils releasing free fatty acids and glycerol. Additionally, they participate in esterification and transesterification reactions, lactonization, aminolysis [1], acidolysis [2], aminolysis, alcoholysis, hydrolysis [3], [4] and interesterification reactions in non-aqueous media [5]. These applications are however due to the potentials of lipases to catalyze both synthetic and hydrolytic processes. Worthy of note also, is their possession of distinctive properties such as, non-requirement of cofactors [2], wide spectrum of substrate specificities, stereoselectivity, chemoselectivity, regioselectivity, stability in organic solvents and their ability to catalyze varied reactions in both water soluble and non-water soluble systems [3]. Lipases of microbial origin differ based on the strain of the organism, composition of the growth medium, sources of nitrogen, temperature, carbon and $\mathrm{pH}$ [6], [7].

The all-round properties of lipases make them to have many potential applications in diverse aspects including, food processing, detergent, pharmaceutical, cosmetics, textile, agrochemical [6], paper, dairy, oleo-chemicals and leather industries [2]. They also find usefulness in the management of waste water, fine chemicals synthesis [6] and the production of other important bioactive compounds such as polyunsaturated fatty acids and carotenoids [8]. Fungi mostly produce lipases extracellularly thereby 
making their extraction easy. Fungi and other microorganisms that produce lipases are present in different habitats such as, crude and vegetable oil contaminated soils, decaying foods, oil seeds [2], fish intestine [6].

Soils particularly the ones contaminated with vegetable oil have been reported to contain lipolytic enzymes which often degrade the fats and oils in them [9]. Filamentous fungi of the many species of genera Mucor, Candida [10], Aspergillus, Rhizopus, penicillium and trichoderma have been reported to be the most prospective lipase producers [11] but despite this, many microorganisms having the ability to produce lipases which are able to breakdown fats and oils are yet to be isolated, identified and characterized [6]. [25] reported that only a very small number (about 2\%) of microorganisms have been used as sources of enzyme in the whole wide world which have served mankind for the different products they are used to produce. Submerged fermentation is preferred to solid state fermentation because of the fact that growth conditions are easily controlled but the cost of substrates for enzyme production still remains a problem for any successful enzyme application presenting about $10-30 \%$ of the overall costs [1]. Therefore, in the present investigation, lipases production was carried out using submerged fermentation and olive oil as a substrate; production and characterization of lipases from two fungal strains were carried out with possible characteristics for desired applications.

\section{Materials and Methods}

\subsection{Sample Collection}

Soil samples were collected into sterile plastic bags from the dump site of Grand Cereals Limited Factory, Plateau State, Nigeria (known mainly for the production of Grand Pure Soya Oil) using a sterile spatula after which they were placed immediately in a flask packed with ice and brought to the laboratory. The samples were sealed in sterile containers and stored in the refrigerator at $4^{\circ} \mathrm{C}$ until required for further usage.

\subsection{Isolation and Identification of Lipolytic Fungal Species from Vegetable Oil Contaminated Soil}

A six-fold serial dilution of the soil samples was made in sterile distilled water followed by the addition of $1 \mathrm{~mL}$ inoculum of $10^{4}$ dilution on sabouraud dextrose agar (SDA) media. The fungal inoculated plates were incubated at $25{ }^{\circ} \mathrm{C}$ for 5 days. Colonies which appeared were subcultured in order to have a pure culture of each isolate and stored in SDA slants at $4{ }^{\circ} \mathrm{C}$. Identification of the isolates was carried out by observing their growth features (such as pigmentation, texture and form) and microscopically based on the growth from their aerial hyphae and structures like conidia, spores, hyphae and sporangiophore or conidiophore.

\subsection{Preliminary Screening for Lipase Producers}

The fungal isolates were screened by their ability to produce lipase following incubation on SDA media supplemented separately with $3 \%$ (v/v) olive oil and analyzing the formation of clear zones around colonies according to the method described by [7]. The abilities of the isolates to produce lipase were at that moment compared by measuring the zone of clearance. Isolates having lipolytic halo radius (R) / colony radius (r) ratio of greater than $5 \mathrm{~mm}$ were selected for further studies.

\subsection{Production of Lipase from Selected Fungal Strains of Vegetable Oil Contaminated Soil}

Lipase production was carried out in broth containing (g/500 mL): $\mathrm{MgSO}_{4} \cdot 7 \mathrm{H}_{2} \mathrm{O}(0.1), \mathrm{KH}_{2} \mathrm{PO}_{4}(0.5), \mathrm{K}_{2} \mathrm{HPO}_{4}$ (1.5), $\mathrm{Na}_{2} \mathrm{SO}_{4}$ (1.0), yeast extract (2.5), peptone (2.5), glucose (1.0) and olive oil ( $2 \% \mathrm{v} / \mathrm{v}), \mathrm{pH} 7.0$. Productions were carried out in $50 \mathrm{~mL}$ production media with inoculation of a $6 \mathrm{~mm}$ of the fungal spores inside a $250 \mathrm{~mL}$ Erlenmeyer flasks under shaking speed of $150 \mathrm{rpm}$ at room temperature for successively 7 days. The broth was harvested at $24 \mathrm{~h}$ interval and centrifuged at $4000 \mathrm{rpm}$ for $40 \mathrm{~min}$ at $10{ }^{\circ} \mathrm{C}$ to remove cells. Total protein as well as lipase activity were determined from the supernatant.

\subsection{Assay for Lipase Activity}

Lipase activity was assayed spectrophotometrically at $450 \mathrm{~nm}$ according to the method of [12] with slight modification. To $800 \mu \mathrm{L}$ of substrate solution (containing $3 \% \mathrm{v} / \mathrm{v}$ Tween 80 in $20 \mathrm{mM}$ Tris- $\mathrm{HCl}$ with $\mathrm{pH}$ of 8.5 and $80 \mathrm{mM} \mathrm{CaCl}_{2}$ ), $200 \mu \mathrm{L}$ of the enzyme was added. The hydrolysis rate of Tween 80 was monitored directly by measuring the change in absorbance over a period $5 \mathrm{~min}$.

\subsection{Total Protein Determination}

Protein concentration was measured spectrophotometrically at $590 \mathrm{~nm}$ as described by [13]. 1 $\mathrm{mL}$ of the sample was added to $5 \mathrm{~mL}$ of Bradford reagent, the mixture was allowed to stand for $5 \mathrm{~min}$ at room temperature after which absorbance was read. Total protein was determined by extrapolating from the egg albumin (EA) standard curve which was constructed using a solution containing $1 \mathrm{mg} / \mathrm{mL}$ EA.

\subsection{Biochemical Characterization of Lipases from Fungal Isolates of Vegetable Oil Contaminated Soil}

\subsubsection{Effect of $\mathrm{pH}$}

The effect of $\mathrm{pH}$ on the activity of lipases was studied by 
incubating $200 \mu \mathrm{L}$ of the enzymes with $1 \mathrm{M}$ Tris-HCl buffer over a $\mathrm{pH}$ range of 4 to 10 and assayed for lipase activity. A plot of lipase activity against $\mathrm{pH}$ was used to determine the optimum $\mathrm{pH}$ for the lipases.

\subsubsection{Effect of Temperature}

The effect of temperature on the activity of lipases was studied by assaying from lipase activity followed by incubation at temperature range of 20 to $55^{\circ} \mathrm{C}$. A plot of lipase activity against temperature was used to determine the optimum temperature of activity for the lipases.

\subsubsection{Effect of Different Substrates on Lipase Activity}

The effect of different substrates on lipase activities was studied; $1 \%$ Tween 80 was substituted with olive oil, palm oil and groundnut oil and assayed as described above.

\subsubsection{Effect of Different Metal Ions on Lipase Activity}

The effect of different metal ions on lipase activities was studied by using $\mathrm{K}^{+}, \mathrm{Co}^{2+}, \mathrm{Mg}^{2+}, \mathrm{Hg}^{2+}, \mathrm{Cu}^{2+}, \mathrm{Ca}^{2+}$ and $\mathrm{Fe}^{3+}$. $0.2 \mu \mathrm{L}$ of $1 \mathrm{mM}$ of each metal ion already prepared in $1 \mathrm{M}$ Tris-HCl buffer was added to the substrate mixture and treated as described in assay for lipase activity above.

\subsubsection{Determination of $\mathrm{K}_{\mathrm{m}}, \mathrm{V}_{\max }$ and $\mathrm{K}_{\text {cat }}$}

The kinetic constants $K_{m}$ and $V_{\max }$ for lipases were determined from the Lineweaver - Burk plot following a change in substrate concentration over the range of $0.02-$ $1.80 \mathrm{v} / \mathrm{v}$ of Tween 80 and assayed. $\mathrm{K}_{\text {cat }}$ of the lipases were as well determined.

\subsubsection{Thermal Inactivation Studies}

The thermal inactivation studies was carried out in a water bath over temperature range of $20-90{ }^{\circ} \mathrm{C}$ using $1 \mathrm{M}$ Tris-HCl buffer for $30 \mathrm{~min}$. Thereafter, the test tubes were allowed to cool to room temperature and assayed for lipase activity. Arrhenius plot was used to determine the energy of deactivation for the enzymes as thermal inactivation usually follows the first order kinetics [14]. The residual activity of the enzymes was also calculated in order to determine the half-life of the enzymes.

\subsection{Statistical Analysis}

Experiments were performed in triplicates and the means of results determined were calculated using Statistical Package for Social Science (SPSS) version 23.

\section{Results and Discussion}

Fungi are good sources of enzymes and reports from previous literatures have it that soils contaminated with oil often retain microbial diversity [15]. Out of the 9 fungi isolated from the vegetable oil contaminated soil following incubation on SDA, 5 isolates exhibited different magnitudes of zones of clearance when $3 \%$ olive was used as a substrate (Table 2). This indicates the occurrence of degradation reaction of olive oil by extracellular enzymes, inducing the production of the lipase enzyme. From the 5 lipase producers, Yeast and Microsporum canis being the best with zones of hydrolysis of 5.63 and $5.16 \mathrm{~mm}$ respectively were selected for lipase production and characterization. Various microorganisms such as bacteria, fungi and yeast are recognised as potential producers of enzymes which employ these enzymes in nutrients degradation process [6].

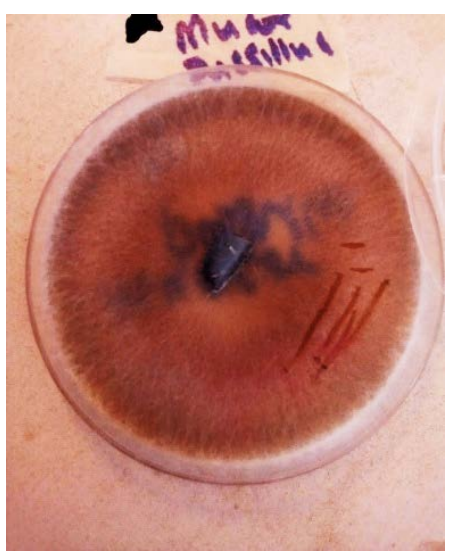

Plate I

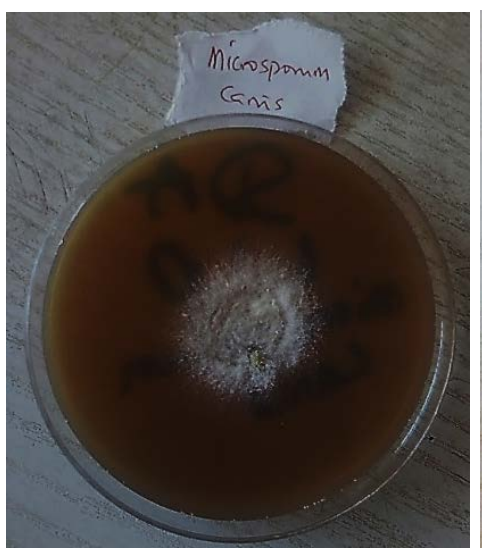

Plate II

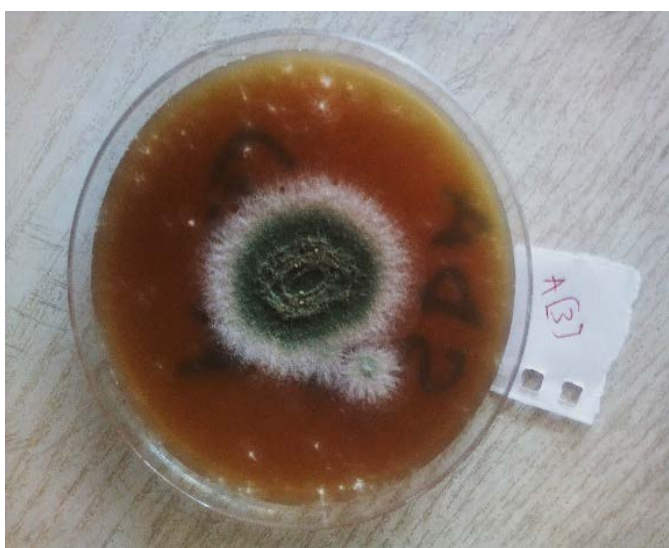

Plate III 


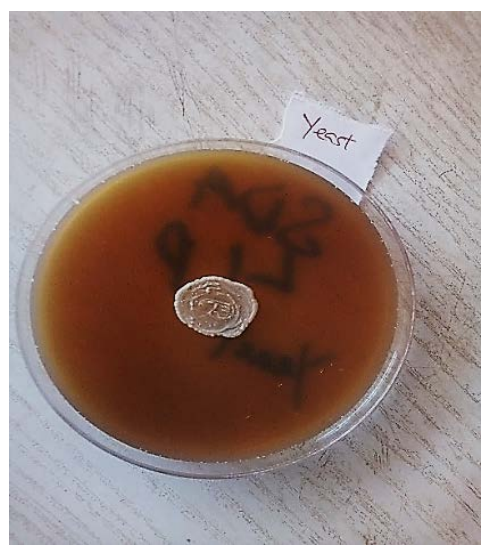

Plate IV

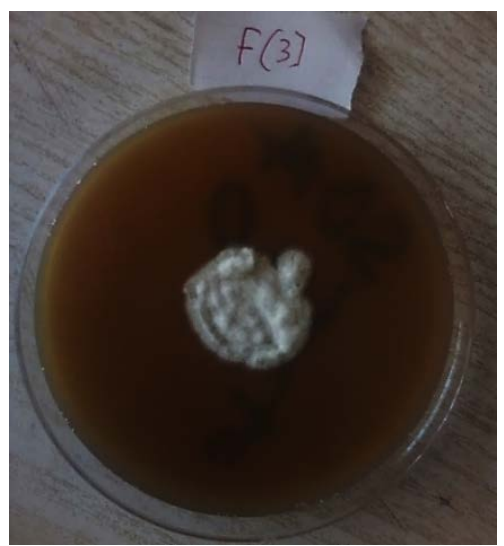

Plate V
Plates I - V: Morphological

features of fungal isolates from a vegetable oil contaminated soil;

I - Mucor pusillus,

II - Microsporum canis,

III - Aspergillus fumigatus,

IV - Yeast,

$\mathrm{V}$ - Trichophyton mentagrophyte

Table 1. Zone of hydrolysis of fungal isolates from a vegetable oil contaminated soil

\begin{tabular}{|c|c|c|}
\hline S/No & Fungal isolate & Zone of hydrolysis (mm) \\
\hline 1 & Mucor pusillus & $4.18 \pm 0.01$ \\
\hline 2 & Microsporum canis & $5.16 \pm 0.02$ \\
\hline 3 & Aspergillus fumigatus & $3.27 \pm 0.02$ \\
\hline 4 & Yeast & $5.61 \pm 0.02$ \\
\hline 5 & Trichophyton mentagrophyte & $1.82 \pm 0.10$ \\
\hline
\end{tabular}

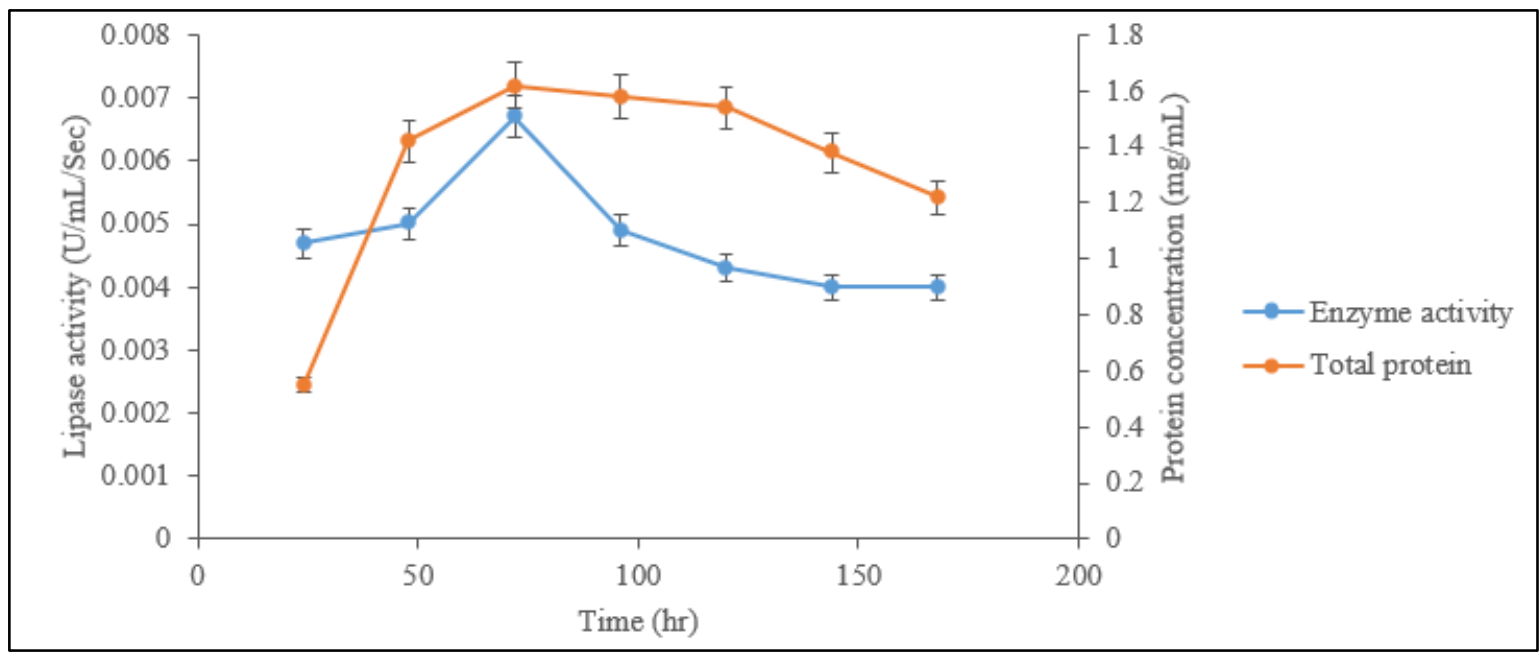

Figure 1. Effect of incubation time on lipase production by Yeast isolated from a vegetable oil contaminated soil

Quantitative lipase production was carried out using submerged fermentation for a period of 7 days during which lipase activity and total protein were determined. Both Yeast and Microsporum canis produced lipases maximally at $72 \mathrm{~h}$ (Figures 1 and 2). A number of other studies also reported lipase production by submerged fermentation. [16] reported maximum lipase production from Candida rugosa at $50 \mathrm{~h}$ using olive oil as a substrate and [17] on the other hand reported maximum lipase production using olive mill wastewater from Candida cylindracea NRRLY-175 at 175 h. The time of incubation for enzyme production is usually guided by the characteristics of the culture medium and is dependent on growth rate [18].

Lipase from Yeast had an optimum pH of 5 while that from $M$. camis was determined to be 6 (Figure 3). Various studies with lipases reported acidic $\mathrm{pH}$ values which correlate with the acidic $\mathrm{pH}$ values of the present study. [19] reported an optimum $\mathrm{pH}$ of 6.5 from $A$. niger and [8] reported a $\mathrm{pH}$ value of 5.2 for the $R h$. oryzae enzyme studied. Both lipases found in the present study may be useful in the leather industry because the use of acidic active lipases has been reported in the treatment of animal skins which have been kept in pickled form [8]. 


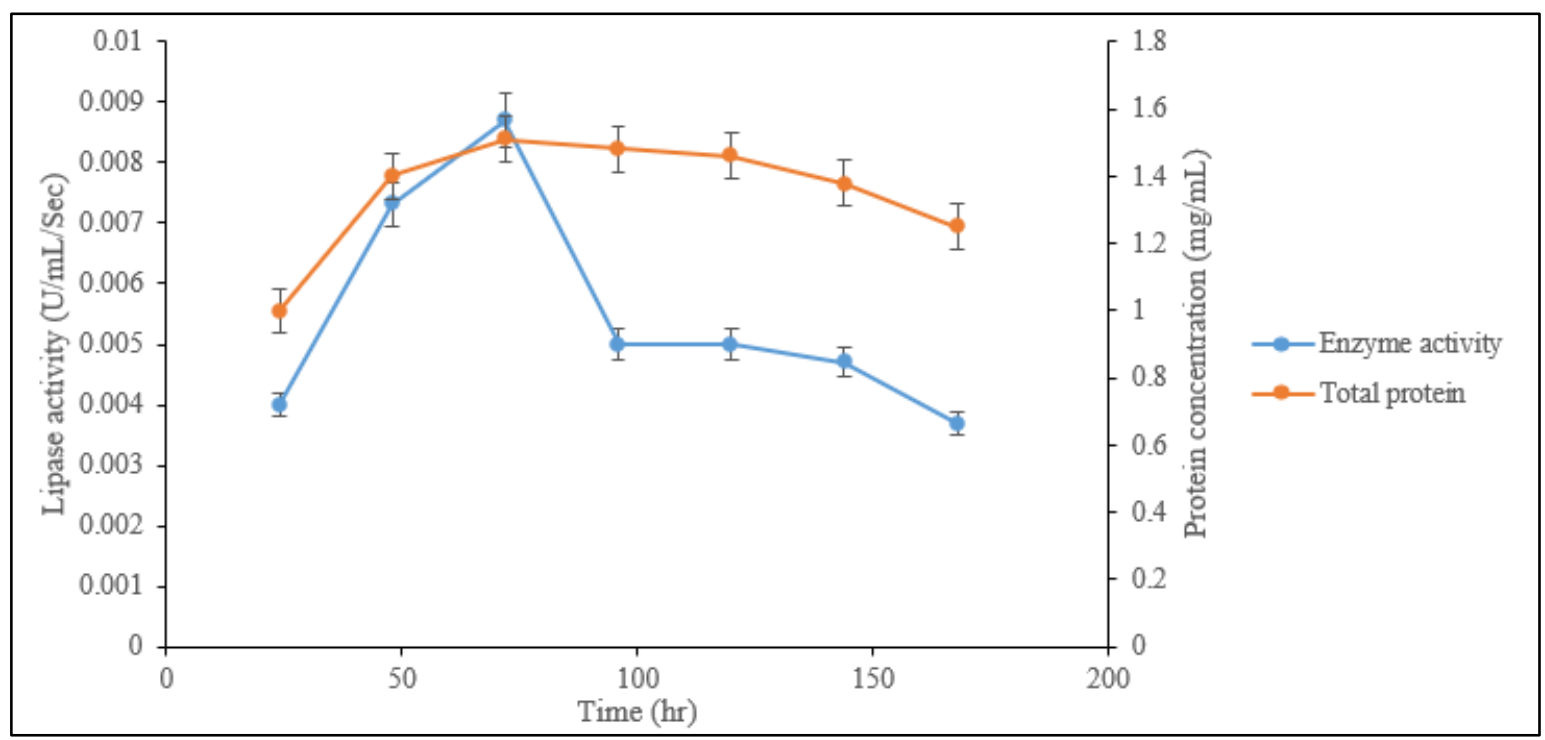

Figure 2. Effect of incubation time on lipase production Microsporum canis isolated from a vegetable oil contaminated soil

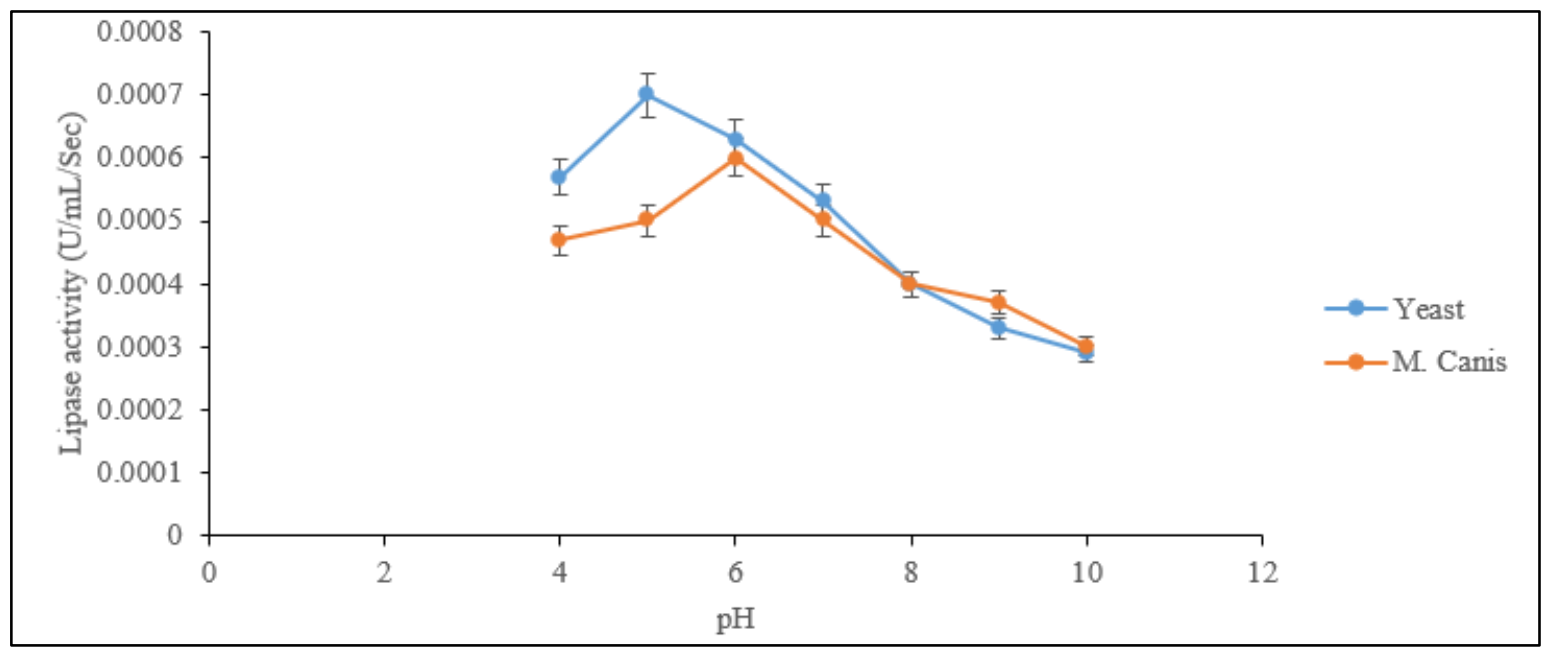

Figure 3. Effect of pH on the activity of lipases from fungal isolates of a vegetable oil contaminated soil

Figure 4 presents the optimum temperature of activity of lipases from Yeast and M. canis isolates of a vegetable oil contaminated soil. Optimum lipase activities were determined to be 35 and $40{ }^{\circ} \mathrm{C}$ for Yeast and and M. canis respectively. [19] reported $30-35{ }^{\circ} \mathrm{C}$ as the optimum temperature for an olive oil-induced lipase from Aspergillus niger MYA 135 while [14] reported that lipase from Cellulomonas flavigena UNP3 was optimally active at $30{ }^{\circ} \mathrm{C}$. The optimum temperature obtained for lipase from Yeast corresponds to the highest temperature as reported by [19] and that of lipase from $M$. canis tallies with the optimum temperature of $40{ }^{\circ} \mathrm{C}$ as reported by [20] and [21] from Aneurinibacillus aneurinilyticus strain LP-II and $A$. niger respectively. Both lipases from Yeast and $M$. canis had moderate temperature values making them possibly useful in bioprocesses operating at moderate temperatures.

Palm, groundnut and olive oils were substituted with tween 80 in order to determine their effects on lipase activities (Table 2). Generally, activities were found to be highest when olive oil was used as a substrate in this study. Palm and vegetable oils had the same activities for the lipase enzyme from Yeast while the lipase from M. canis had preference for palm oil to vegetable oil. The findings of the present study conform to those of other studies [22], [23], [24] suggesting olive oil as potent substrate for lipases.

Table 2. Effect of different substrates on the activity of lipases from fungal isolates of a vegetable oil contaminated soil

\begin{tabular}{|c|c|c|c|}
\hline \multirow{2}{*}{ Isolate } & \multicolumn{3}{|c|}{ Lipase activity $(\mathrm{U} / \mathrm{mL} / \mathrm{Sec})$} \\
\cline { 2 - 4 } & Palm oil & Groundnut oil & Olive oil \\
\hline \multirow{2}{*}{ Yeast } & $0.0007 \pm$ & $0.0007 \pm 5.8 \times$ & $0.0008 \pm$ \\
& $1.2 \times 10^{-4}$ & $10^{-5}$ & $5.8 \times 10^{-5}$ \\
\hline Microsporum & $0.0005 \pm$ & $0.0004 \pm 1.2 \times$ & $0.0006 \pm$ \\
canis & $5.8 \times 10^{-5}$ & $10^{-4}$ & $5.8 \times 10^{-5}$ \\
\hline
\end{tabular}




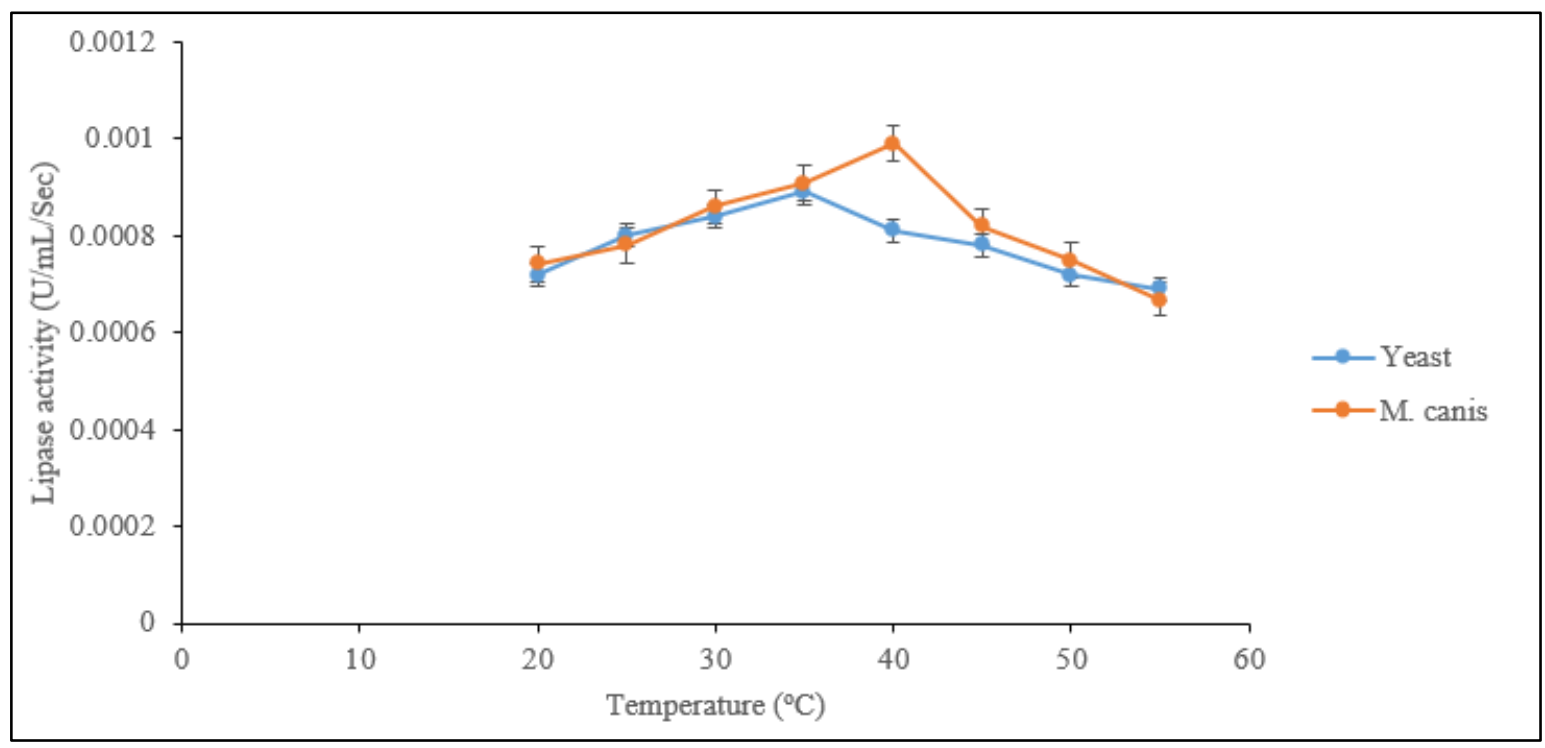

Figure 4. Effect of temperature on the activity of lipases from fungal isolates of a vegetable oil contaminated soil

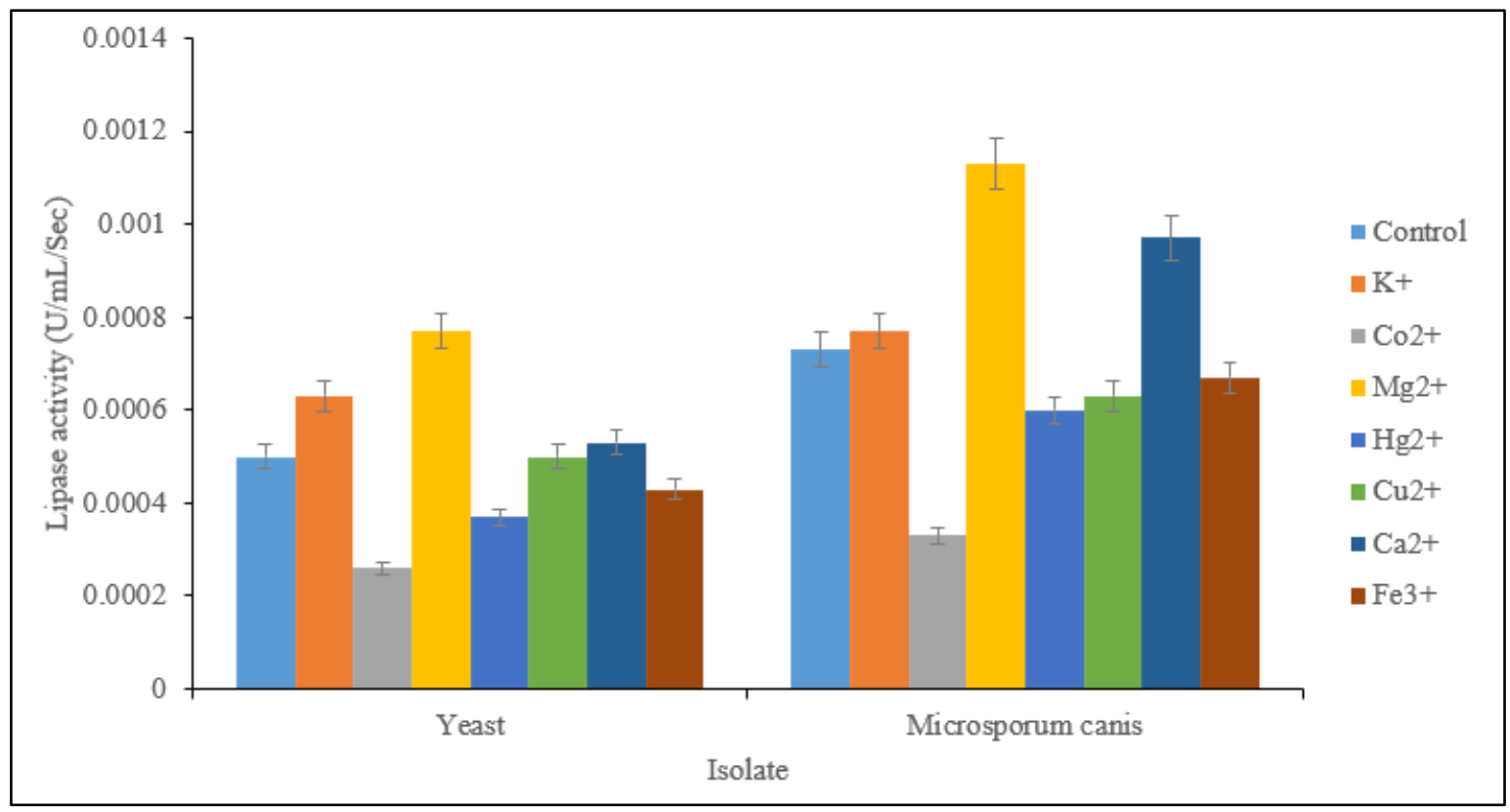

Figure 5. Effect of different metal ions on the activity of lipases from fungal isolates of a vegetable oil contaminated soil

The effect of metal ions on the activities of lipases from Yeast and $M$. Canis were investigated and the results are shown in Figure 5. While $\mathrm{Cu}^{2+}$ had no effect on lipase activity from Yeast, it inhibited the activity of lipase from M. canis. $\mathrm{K}^{+}, \mathrm{Mg}^{2+}$, and $\mathrm{Ca}^{2+}$ increased the activity of lipases from both Yeast and M. canis. [14] reported an activation of lipase activity by $\mathrm{Mg}^{2+}$ and $\mathrm{Ca}^{2+}$ from different studies which is in tandem to the outcomes of the present study. On the other hand, $\mathrm{Fe}^{3+}, \mathrm{Hg}^{2+}$ and $\mathrm{Co}^{2+}$ showed inhibitory effects for the lipases studied.

Figures 6 and 7 present the Lineweaver-Burk plot for the determination of Km, Vmax and Kcat from Yeast and M. canis. Corresponding Vmax, $\mathrm{Km}$ and Kcat values of $0.0006 \mathrm{U} / \mathrm{mL} / \mathrm{Sec}, 0.4242 \mathrm{mM}$ and $0.0004 \mathrm{~S}^{-1}$ were determined for lipase from Yeast while those from $M$. canis were determined to be $0.0001 \mathrm{U} / \mathrm{mL} / \mathrm{Sec}, 3.2287$ $\mathrm{mM}$ and $0.0001 \mathrm{~S}^{-1}$ respectively. Other studies with lipases reported higher $\mathrm{Km}$ values compared to the result of lipase from Yeast; [1] determined a Km value of 9.93 $\mathrm{mM}$ for lipase from Penicillium $s p$. using $p$-Nitrophenyl palmitate as a substrate and [8] found an estimated value of 1.13 and $1.08 \mathrm{mM}$ for purified lipases corresponding to Rhizomucor miechei and Rhizopus oryzae using $p$-nitrophenyl palmitate ( $p$ NPP) as substrate. It can therefore be concluded that lipases from Yeast has higher affinity for the substrate than the already mentioned suggesting it to be a potential biotechnological machinery. 


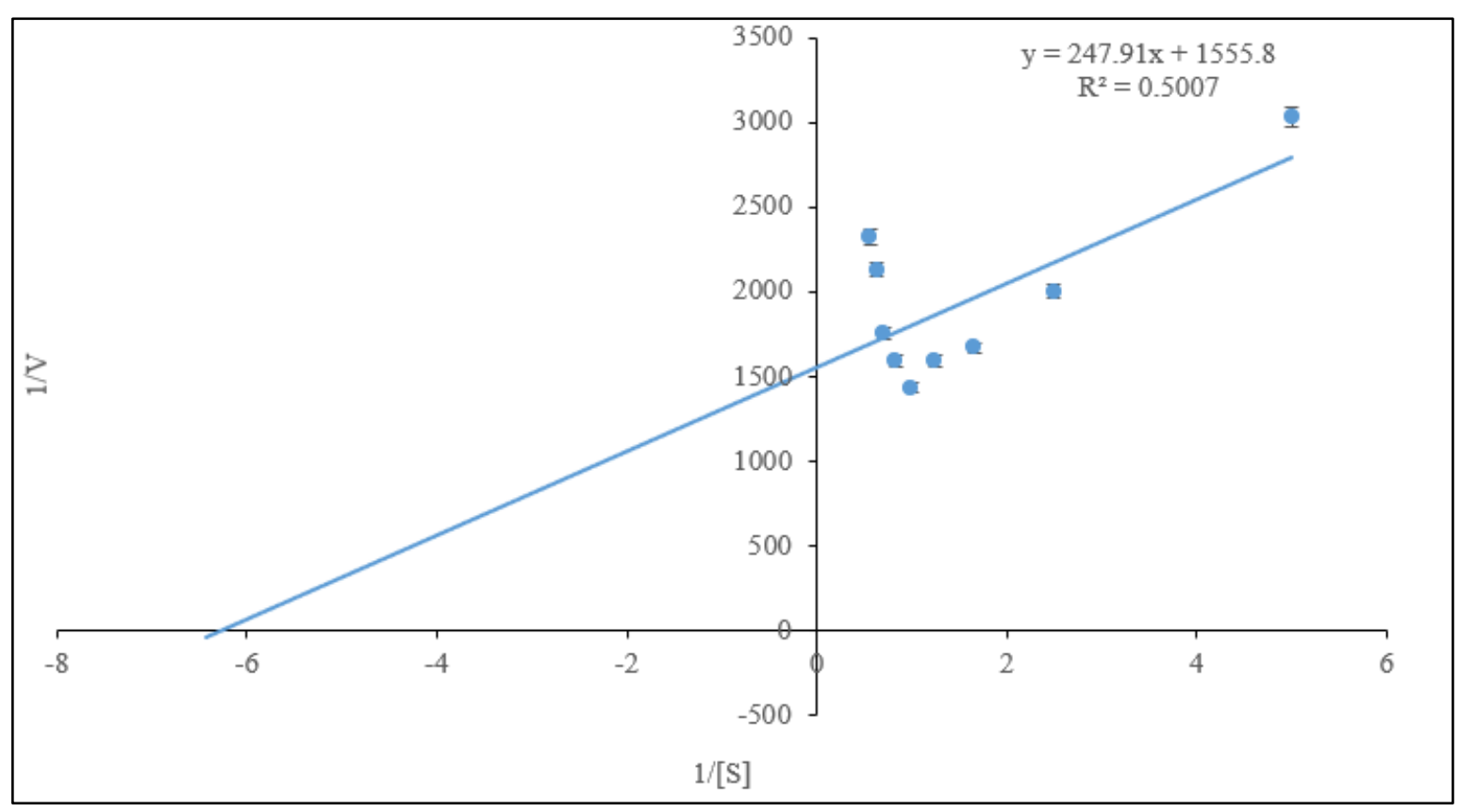

Figure 6. Lineweaver-Burk plot of lipase from Yeast isolated from a vegetable oil contaminated soil

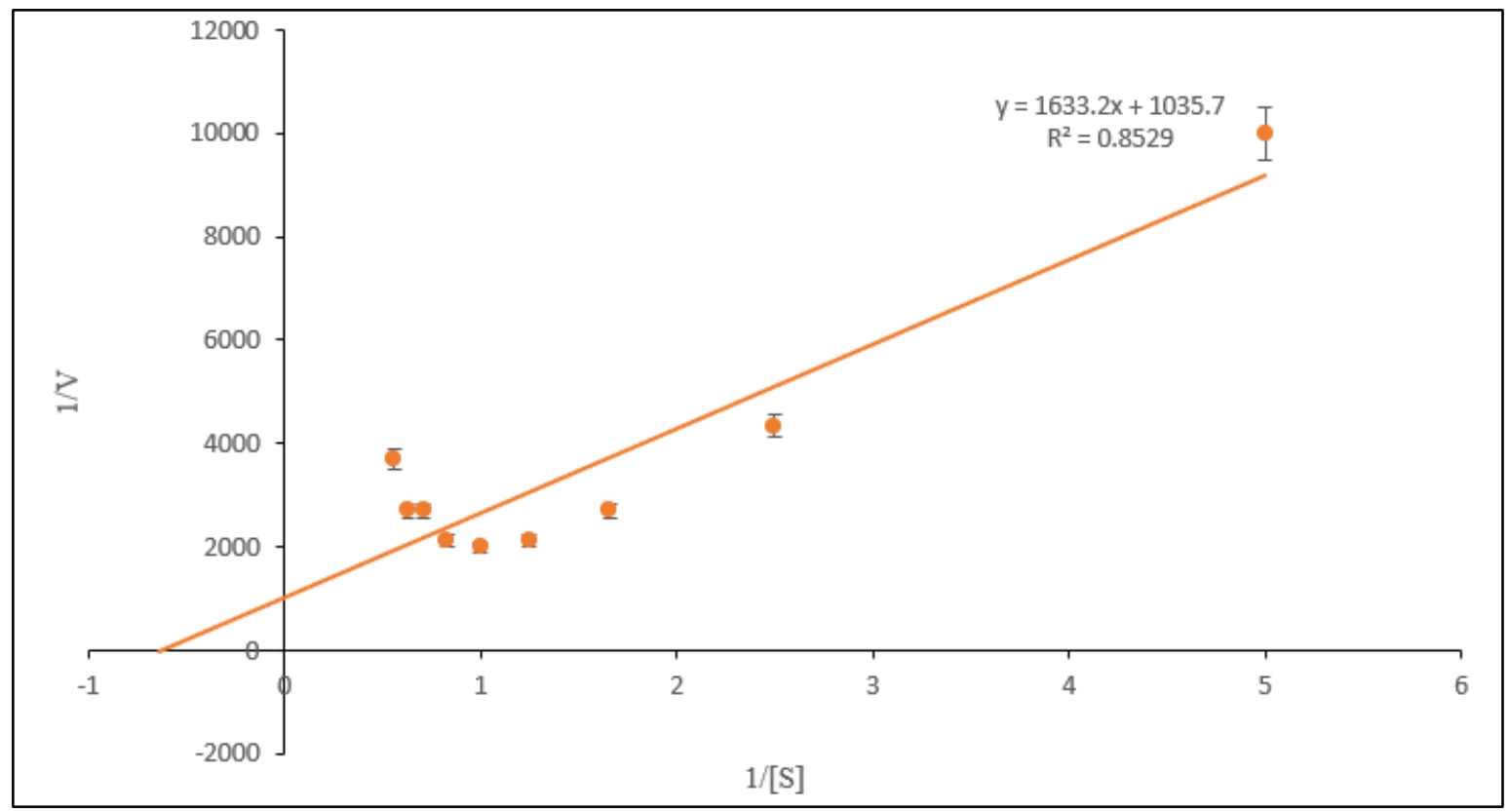

Figure 7. Lineweaver-Burk plot of lipase from Microsporum canis isolated from a vegetable oil contaminated soil

Lipases from Yeast and $M$. canis had energy of deactivation values of 22.871 and $17.923 \mathrm{KJ} / \mathrm{mol}$ respectively (Figures 8 and 9). The energy of deactivation determined in the present study were lower than the value of $64.32 \mathrm{KJ} / \mathrm{mol}$ of lipase from Cellulomonas flavigena UNP3 earlier reported by [14]. The calculated half-life for lipase from Yeast was $0.23 \mathrm{hr}$ whereas that from M. canis was $0.58 \mathrm{hr}$. 


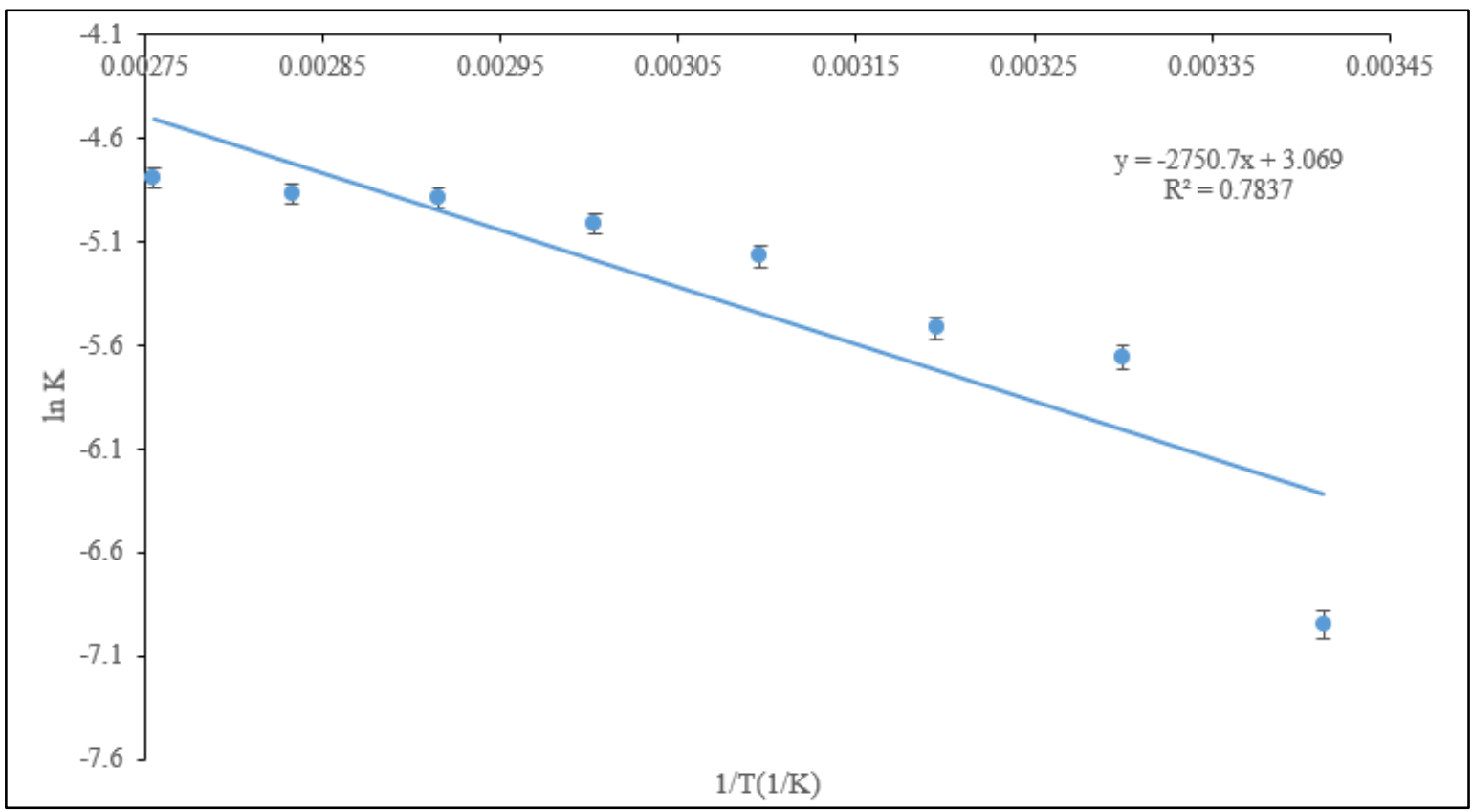

Figure 8. Arrhenius plot for determination of energy of deactivation of lipase from Yeast isolated from a vegetable oil contaminated soil

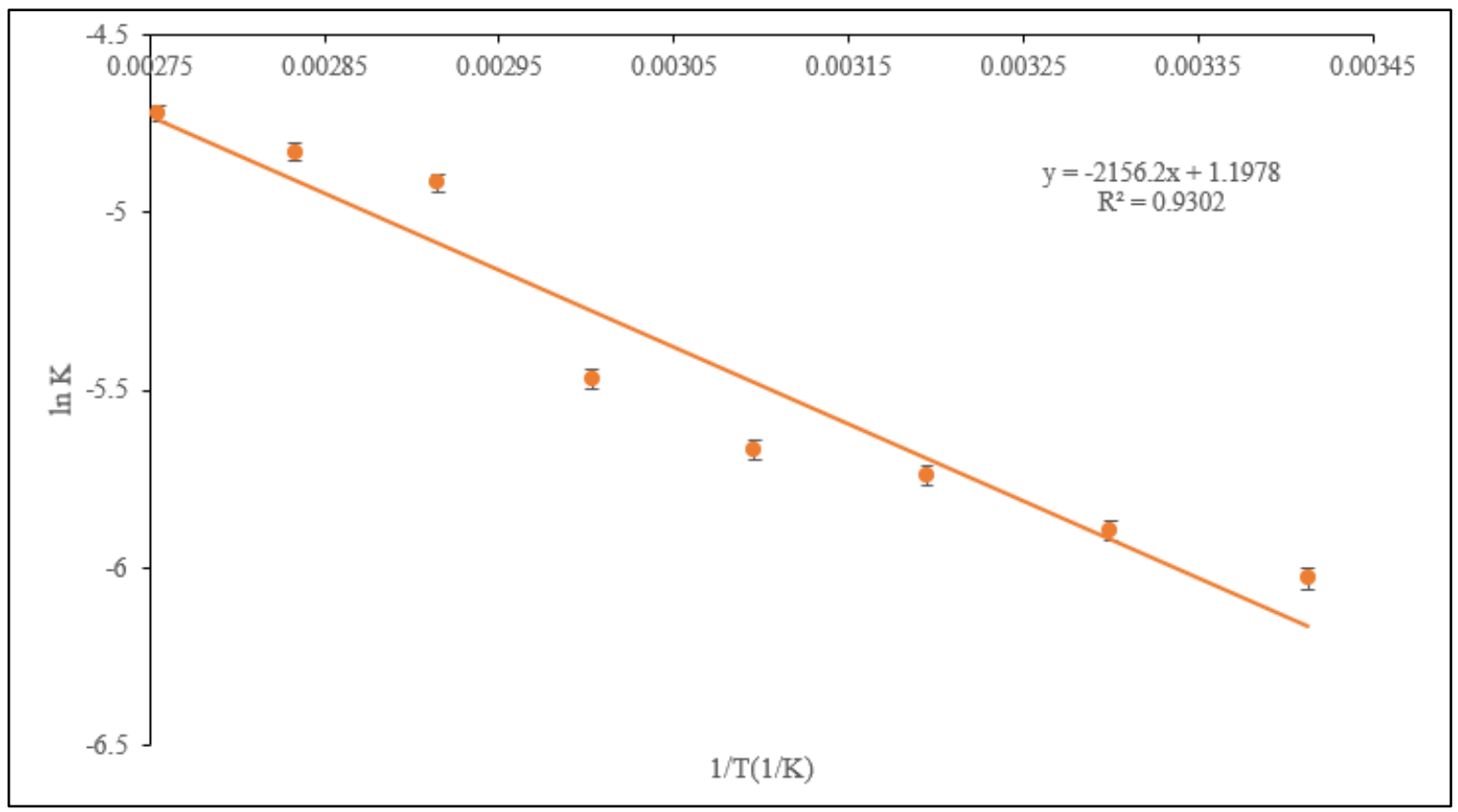

Figure 9. Arrhenius plot for determination of energy of deactivation of lipase from Microsporum canis isolated from a vegetable oil contaminated soil

\section{Conclusions}

Yeast and $M$. canis fungal strains isolated from a vegetable oil contaminated soil were found to be good lipase producers. The lipases studied were optimally active at acidic $\mathrm{pH}$ and at moderate temperature with immense affinities for different substrates. The findings of the present study suggest lipases from these sources could find usefulness in different bioprocesses.

\section{Acknowledgements}

The authors are thankful to TETFund Nigeria for funding this research.

\section{REFERENCES}

[1] A. N. Ferreira, D. D. S. Ribeiro, R. A. Santana, A. C. S. Felix, 
L. D. G. Alvarez, E. de O. Edeltrudes de Oliveira Lima, J. S. D. Freitas, G. L. Valasques, M. Franco, B. B. do N. Junior. Production of Lipase from Penicillium sp. Using Waste Oils and Nopalea cochenillifera. Chemical Engineering Communications, DOI: 10.1080/00986445.2017.1347567, 2017.

[2] A. Mehta, U. Bodh, R. Gupta. Fungal Lipases: A Review. Journal of Biotechnology and Research, 8, 58 - 77, 2017.

[3] M. Patel, J. Mistry, S. Desai, S. Patel, S. Desai. Isolation and Characterization of Lipase Producing Bacteria from Vegetable Oil Spillage Site. International Journal of Current Microbiology and Applied Sciences, 5(8): 214 -232, 2016.

[4] B. Sreelatha, V. Koteswara Rao, R. Ranjith Kumar, S. Girisham, S. M. Reddy. Culture Conditions for the Production of Thermostable Lipase by Thermomyces lanuginosus. Beni - Suef University Journal of Basic and Applied Sciences, 6(2017), 87 - 95, 2-016.

[5] H. Kandala, D. Roy, M. Sathiavelu, S. Arunachalam, K. Loganathan. Isolation and Characterization of Lipase Producing Bacteria from Vellore Soil. Pharmacologyonline, 2, 356 - 361, 2010.

[6] N. C. Ariole, G. D. Bagshaw. Optimization of Culture Conditions for Lipase Production by Micrococcus Sp. Isolated from Farmed Clarias gariepinus Intestine. International Journal of Biological Sciences and Applications, 1(3), 79 - 83, 2010.

[7] Z. A. Ayinla, A. N. Ademakinwa, F. K. Agboola. Studies on the Optimization of Lipase Production by Rhizopus sp. ZAC3 Isolated from the Contaminated Soil of a Palm Oil Processing Shed. Journal of Applied Biology \& Biotechnology, 5(2), 030 - 037, 2017.

[8] M. Takó, A. Kotogán, T. Papp, S. Kadaikunnan, Naiyf S. Alharbi, C. Vágvölgyi. Purification and Properties of Extracellular Lipases with Transesterification Activity and 1,3-Regioselectivity from Rhizomucor miehei and Rhizopus Oryzae. Journal of Microbiology and Biotechnology, 27(2), $277-288,2017$.

[9] N. F. Niyonzima, S. More. Biochemical Properties of the Alkaline Lipase of Bacillus flexus XJU-1 and its Detergent Compatibility. Biologia, 69(9), 1108 - 1117, 2014.

[10] N. Pandey, K. Dhakar, R. Jain, A. Pandey. Temperature Dependent Lipase Production from Cold and $\mathrm{pH}$ Tolerant Species of Penicillium. Mycosphere, 7(10), 1533 - 1545, 2016.

[11] H. Musa, B. C. Adebayo-Tayo. Screening of Microorganisms Isolated from Different Environmental Samples for Extracellular Lipase Production. AU Journal of Technology, 15(3), 179 - 186, 2012.

[12] F. J. Plou, M. Ferrer, O. M. Nuero, M. V. Calvo, M. Alcalde, F. Reyes, A. Ballesteros. Analysis of tween 80 as an esterase/lipase substrate for lipolytic activity assay. Biotechnology Techniques, Vol.12, No.30, 183 - 186, 1998.

[13] M. M. Bradford. A rapid and sensitive method for the quantitation of microgram quantities of protein utilizing the principle of protein-dye binding. Analytical Biochemistry, Vol.72, 248 - 254, 1976.

[14] V. Prajapati, H. Patel, U. Trivedi, K. Patel. Kinetic and thermodynamic characterization of lipase produced by Cellulomonas flavigena UNP3. Journal of Basic Microbiology, 54, 976 - 983, 2014.

[15] T. Wadia, S. K. Jain. Isolation, Screening and Identification of Lipase Producing Fungi from Oil Contaminated Soil of Shani Mandir Ujjain. International Journal of Current Microbiology and Applied Sciences, 6(7): 1872 - 1878, 2017.

[16] A. Rajendran, A. Palanisamy, V. Thangavelu. Evaluation of Medium Components by Plackett-Burman Statistical Design for Lipase Production by Candida rugosa and Kinetic Modeling. Chinese Journal of Biotechnology. 24(3), 436 444, 2008.

[17] V. Brozzoli, S. Crognale, I. Sampedro, F. Federici, A D'Annibale, M. Petruccioli. Assessment of Olive-mill Wastewater as a Growth Medium for Lipase Production by Candida cylindracea in Bench-top Reactor. Bioresource Technology, 100, 3395 - 3402, 2009.

[18] K. G. Sahu, M. Martin. Optimization of Growth Conditions for the Production of Extracellular Lipase by Bacterial Strains from Dairy Industry Effluents. Biotechnology Bioinformatics and Bioengineering, 1(3), 305 - 311, 2011.

[19] M. L. Pera, M. C. Romero, D. M. Baigori, R. G. Castro, G.R. Catalytic Properties of Lipase Extracts from Aspergillus niger. Food Technology and Biotechnology, 44(2): 247 252, 2006.

[20] D. B. Chavan, C. N. Khobragade. Characterization of Lipase Produced by Aneurinibacillus aneurinilyticus Strain LP-II Isolated from Soil of Oil Mill. Journal of Innovations in Pharmaceutical and Biological Sciences (JIPBS), 4 (4), 158 - 161, 2017.

[21] D. Sarkar, S. Laha. Optimization of Extracellular Lipase Enzyme Production from Aspergillus niger by Submerged and Solid State Fermentation Process. International Journal of Pharma and Bio Sciences, 4(4), 978 - 985, 2013.

[22] R. Sharma, Y. Chisti, U. C. Banerjee. Production, Purification, Characterization, and Applications of Lipases. Biotechnology Advances, 19, 627 - 662, 2001.

[23] O. Moftah, S. Grbavčić, S. A. W. Moftah, D. N. Lukovic, O. Prodanović, M. S. Jakovetic, Z. Knežević-Jugović. Lipase Production by Yarrowia lipolytica Using Olive Oil Processing Wastes as Substrates. Journal of the Serbian Chemical Society, 78, 781 - 794, 2013.

[24] A. Muthusamy, L. G. Beslin.. Extra Cellular Lipase Production, Purification and Characterization Using Bacillus subtilis in Submerged State Fermentation. Biomedical Journal of Scientific and Technical Research, 10(2), 7641 7645, 2018.

[25] Sharada, B. \& Ramakrishna (2016). Molecular Characterization and Partial Purification of Lipase from Lipolytic Bacteria Isolated from Oil Mills. European Journal of Biotechnology and Bioscience, 4(6), 13 - 19. 